\title{
PERAN MUSEUM BRAWIJAYA SEBAGAI WAHANA INTERNALISASINILAI-NILAI KEBANGSAAN
}

\author{
Auliah Safitri \\ FKIP Universitas Muhammadiyah Malang, Indonesia \\ Email: auliah@gmail.com
}

\begin{abstract}
To build Indonesia should be grounded on the values of the existing nationality. But at present, these values began to fade. The next generation is losing confidence in their nation. So need an effort to make national values can flourish and inspired by all the people to build the nation's character. Brawijaya Museum is one of the institutions that can strengthen the character of nationalism youth through collections owned. This is a descriptive study using qualitative methods. Its collection techniques are observation, interviews, and documentation. The method are data analysis, data reduction, data presentation, and conclusions. The results showed that: a) Museum Brawijaya as a form of role in the values of nationality is to tell museum collections to visitors and participate or actively in exhibitions organized by relevant institutions, b) Management of the museum include ways attract the attention of visitors, human resources, funding, technical management of the collection and management of the library, c) Visitors response after visiting the museum is satisfied that a lot of national values that they can get that put the interests of the nation above personal interests, capable and willing to sacrifice for the nation and country, love homeland and nation, proud nation and state of Indonesia, uphold the unity of the nation and the state.
\end{abstract}

Keywords: Museum; Internalization; Nationality Values

\section{PENDAHULUAN}

Tokoh Ki Hadjar Dewantara (dalam Sutrisno, 1988) menyatakan "terjadinya persatuan rakyat yang bersifat Bangsa itu tidak dengan seketika, akan tetapi lambat laun dengan melalui waktu yang berabadabad, dalam waktu mana terbuktikanlah persatuan perikehidupan yang tersebut diatas itu, teristimewa bersatunya nilainilai kebatinan, yaitu tambo, bahasa, seni, agama, dan pengetahuan".

Jika pun kebangsaan itu dilihat secara mikro dalam kedudukannya sebagai komponenPancasila, kontekskebudayaannya tetap muncul secara prinsipil oleh kaidah keterkaitan sila-sila yang ada. Dengan begitu sila ke-3 (kebangsaan) akan dijiwai oleh sila ke-2 (kemanusiaan) yang memperoleh dasar moralnya dari sumber sila pertama (Ketuhanan Yang Maha Esa). Bahkan semenjak pidato Lahirnya Pancasila 1 Juni 1945, Bung Karno menyatakan pertalian erat antara nasionalisme (kebangsaan) dengan internasionalisme (kemanusiaan).
Menurut artian makro lebih-lebih kebangsaan sebagai suatu kesatuan rasa kebatinan secara evolutif menjadi wahana kehidupan dan kebudayaan Indonesia. Wahana kebangsaan inilah yang telah memberi derajad pensifatan yang tinggi kepada Pancasila sebagai ideologi begitu rupa, sehingga kita akan menyebutnya sebagai ideologi kebangsaan, yang tumbuh di sepanjang garis perkembangan kebudayaan Indonesia dengan sendi kefalsafahan yang secara genetis merupakan artikulasi potensia-potensia internal.

Kebangsaan dan nasionalisme sering dianggap sinonim dan dalam pengertiannya berada dalam suatu kategori reaktif, sebagaimana dari sumbernya di dunia Barat muncul bertalian erat dengan meletusnya revolusi Perancis. Bukan saja dalam perkembangannya ia melebar ke sejumlah negara di Eropa bahkan di kalangan negeri yang digolongkan Dunia Ketiga di kemudian hari diterima sebagai penentang 
terhadap kepenguasaan kolonial. Dalam arti ini nasionalisme dekat sekali dengan pergerakan politik, dengan kaitan yang tidak terlalu erat terhadap falsafah dan kebudayaan sebagai garis penghubung.

Menurut Renan (dalam Musa, 2011) Keberadaan atau ketidak beradaan suatu bangsa tergantung pada kehendak individu: penduduk dari suatu wilayah yang muncul secara historis, yang memandang dirinya sebagai sebuah bangsa dan kewarganegaraan itu disamakan dengan kebangsan. Nation adalah suatu jiwa, suatu asas spiritual. Nation adalah suatu kesatuan solidaritas yang besar, tercipta oleh perasaan pengorbanan yang telah dibuat di masa lampau dan yang oleh manusiamanusia yang bersangkutan bersedia di buat di masa depan. Nation mempunyai masa lampau, tetapi ia melanjutkan dirinya pada masa kini melalui suatu kenyataan yang jelas, yaitu kesepakatan, keinginan yang dikemukakan dengan nyata untuk terus hidup bersama.

Unsur-unsur kebangsaan yang tediri dari rasa, paham, semangat, dan wawasan kebangsaan terjalin dalam satu kesatuan. Dengan demikian, nasionalisme pada dasarnya merupakan pandangan, perasaan, wawasan, sikap dan perilaku suatu bangsa yang terjalin secara bersama-sama sehingga sulit untuk dipisahkan antara warga negara dengan negaranya. Nasionalisme merupakan nyawa bagi negara tersebut. Dengan kata lain, nasionalisme merupakan sikap hidup untuk menjadikan suatu bangsa yang merdeka secara bersamsama, bukan sekedar kebersamaan untuk menghalau secara fisik kolonialisme dan imperialisme karena persamaan nasib sepenaggungan dalam perjuangan fisik, tetapi lebih jauh dari itu, yakni untuk mengantarkan negara-bangsa mencapai cita-cita adil berkemakmuran dan makmur berkeadilan dalam suasana damai, bebas, berkemanusiaan, dan berkedaulatan rakyat.
Sejarah Negara Indonesia berangkat dari pertumbuhan Negara-negara kecil yang berbasis penduduk pribumi dan kerajaan seperti Majapahit, Sriwijaya, Mataram, dan sebagainya yang terberai di bumi Nusantara. Memasuki awal abad ke-20, barulah upaya untuk menyatukan Negara pribumi tersebut dilakukan beriringan dengan berkembangnya nasionalisme di Eropa. Sebelum abad ke-20 kerajaankerajaan yang ada di nusantara belum dapat dikategorikan sebagai Negara kebangsaan. Kerajaan Sriwijaya dan Majapahit memang pernah menjadi Negara besar di Nusantara. Tetapi, kerajaan tersebut masih mencerminkan adanya suatu Negara tradisional. Sriwijaya dan Majapahit belum dapat dikategorikan sebagai Negara modern walaupun beberapa warisan Negara kemaritiman serta tata kelola kehidupan politik, social dan budayanya masih ada yang perlu warisi dan kita kembangkan.Wilayah kerajaan-kerajaan tradisional selalu berubah sesuai dengan kekuatan politik, militer dan ekonomi. Bila penguasa kerajaan kuat, kecenderungan wilayahnya luas. Sebaliknya demikian penguasa kerajaan lemah, wilayahnya menyusut karena beberapa daerah yang jauh dari kerajaan cenderung memisahkan diri.

Terlepas dari Sriwijaya dan Majapahit sebagai Negara tradisional, roh persatuan serta wawasan Nusantara dapat digalih dari sejarah dua kerajaan tersebut. Kedua Negara tersebut berhasil menjadi kerajaan besar karena memperhatikan aspek maritim. Angkatan laut kedua kerajaan berhasil menyatukan dan menjaga wilayah yang cukup besar. Kepemimpinan dari kedua kerajaan berhasil memadukan potensi agraris dan maritim secara cerdas. Hasil bumi yang dihasilkan pertanian dan perkebunan pada saat itu tidak hanya mencukupi kebutuhan masyarakat melainkan juga untuk ekspor. Pelayaran dan perdagangan internasional berkembang dengan aman di waktu dua 
kerajaan besar tersebut berkuasa. Berkat kepemimpinan dari kedua kerajaan tersebut, sebagian besar wilayah Nusantara mampu menjadi Negara yang disegani di zamannya.

Namun wawasan kebaharian yang pernah dimiliki oleh nenek moyang bangsa di Nusantara telah hilang. Penjajah telah memonopoli pelayaan dan perdagangan. Bangsa Nusantara dipaksa tinggal dalam unitunit wilayah yang saling terpisah. Mereka tidak diberi kesempatan mengembangkan pelayaran dan perdagangan yang sebelumnya menjadi mata pencahariannya. Pelayaran dan perdagangan dimonopoli oleh Koninklijke Paketvaart Maattschappj (KPM) yang dibentuk oleh pemerintah kolonial Belanda tahun 1988. Mobilitas manusia dan barang antar pulau dikendalikan dan diawasi oleh penguasa penjajah. Ironisnya aktivitas warga Nusantara dalam bidang pertanian juga dibatasi dan dipersulit. Warga Nusantara tidak diberi kesempatan memiliki lahan untuk perkebunan. Perkebunan dalam skala besar diakui oleh pengusaha swasta asing. Masyarakat pribumi tetap terbelenggu dalam sistem ekonomi tradisional. Dualisme ekonomi yang dikemukakan oleh Boeke bukan disebabkan oleh pribumi yang malas dan tidak kreatif. Pribumi tetap berada dalam tataran ekonomi skala kecil, tradisional dan bahkan menjadi kuli lebih bayak disebabkan oleh kebijakan sistem ekonomi yang tidak memberi peluang berusaha secara adil pada golongan pribumi. Akibat dari kebijakan kolonial tersebut menyebabkan potensi kebaharian dan pengembangan kehidupan agraris tidak dapat berkembang maksimal.

Dampak dari penjajahan yang sulit disembuhkan adalah hancurnya konsep diri yang positifdikalangan pribumi.Penjajahan tidak hanya telah menghancurkan Negaranegara yang berdaulat di Nusantara. Penjajah juga telah menghancurkan mentalitas kebaharian masyarakat Nusantara. Pelayaran dimonopoli oleh kekuatan penjajah. Bangsa
Nusantara dilarang melakukan transaksi jual beli dengan bangsa lain, bahkan berlayar jauh dari tempat tinggalnya sudah dicurigai dan ditangkap. Masyarakat pribumi diletakkan dalam strata terendah setelah Bangsa Eropa dan Timur Asing.

Rivai (2000) Indonesia telah berkembang mental inferior, rendah diri dan kurang percaya diri. Mereka mudah silau dan kagum dengan bangsa asing serta produk-produknya. Banyak warga nusantara yang tidak bangga sebagai bangsa pribumi. Selama penjajahan berlangsung bangsa pribumi diidentikkan sebagai kelompok yang terbelakang, malas, bodoh, dan miskin. Ironisnya banyak warga Nusantara yang percaya dengan kontruksi budaya penjajah. Terjadilah mentalitet inlander pada sebagian besar masyrakat pribumi yang sisa-sisanya sampai saat ini masih nampak perilaku warga Indonesia.

Di era Orde Baru memang sering terjadi pendistorsian paham nasionalisme. Nilai-nilai kebangsaan telah dimanipulasi untuk menutupi kepentingan kelompok penguasa. Ekonomi rakyat tidak mendapat perlindungan yang maksimal. Potensi ekonomi rakyat makin tergerus oleh proses kapitalisme ekonomi global yang menampakkan wajah greedy state. Kapitalisme pinggiran yang berkembang hanya sebagai ersatz kapitalism, kapitalisme semu yang sangat rentan terhadap perubahan.

Perkembangan teknologi dan informasi yang cukup pesat serta tumbangnya kekuatan komunis menjadi dasar diberlakukannya sistem ekonomi yang tidak lagi mengenal batas negara. Dunia seolah telah memasuki masyarakat bebas dan tanpa batas "borderless". Wacana tentang negara dan ideologi nasionalisme seolah tidak lagi diperlukan. Eksistensi negara dianggap hanya akan menghambat arus informasi dan modal. Rezim Orde Baru telah kehilangan topangan legitimasi. Rezim Orde Baru telah gagal mempertahankan Presidennya. Sang Presiden harus mundur 
agar rezim yang dibangun tidak lenyap oleh sapuan dan tuntutan reformasi rezim. Orde Baru masih berusaha berkelit agar tetap kuat. Transisi yang terjadi dari Presiden ke Wakil Presiden tidak banyak membawa perubahan. Eksistensi nasionalisme dan Pancasila makin menghadapi ujian berat di masa reformasi.

Nasionalisme Indonesia yang sejak awal lahir untuk melawan kolonialisme dalam perjalanannya lebih banyak dikendalikan oleh kekuatan kolonialisme yang telah bermetamorfosis di era globalisasi. Banyak pemimpin Indonesia di Era Reformasi lebih memperhatikan kepentingan politik ekonomi internasional dibanding kepentingan rakyat Indonesia. Nasionalisme kerakyatan sering muncul dalam retorika politik namun jarang hadir dalam praktik politik keseharian. Jiwa kebersamaan atau "gotong royong" seolah makin tersisih dalam ruang publik.

Kondisi tersebut membuktikan bahwa eksistensi nasionalisme di awal reformasi tantangannya makin kompleks. Selain keterpurukan dalam bidang finansial dan ekonomi, bangsa Indonesia juga menghadapi guncangan politik dan budaya. Bangsa Indonesia seolah telah kehilangan kepercayaan. Elit tidak percaya dengan dirinya sendiri. Perilaku mereka cenderung korup, elitis dan bergaya selebritis. Politik pencitraan lebih diutamakan dibanding menjalankan pemerintahan secara substansial. Rakyat semakin kesulitan mencari figur teladan. Barangkali ini akibat dari diterapkannya massa mengambang di era Orde Baru. Politik massa mengambang selain menghasilkan massa yang mengambang juga menciptakan elit yang mengambang.

Nasionalisme yang dirintis oleh pendiri bangsa adalah untuk membebaskan bangsa dan negara Indonesia dari kolonialisme dan imperialisme. Mereka menginginkanmelalui realisasinasionalisme bangsa Indonesia dapat menjadi bangsa yang maju, adil dan sejahtera. Namun, kini kekuatan politik ekonomi internasional cenderung mendominasi kebijakan politik, ekonomi dan budaya Indonesia.

Secara konstitusional, Pasal 32 ayat (1) Undang-Undang Dasar Negara Republik Indonesia Tahun 1945 mengamanatkan bahwa "negara memajukan kebudayaan nasional Indonesia di tengah peradaban dunia dengan menjamin kebebasan masyarakat dalam memelihara dan mengembangkan nilai-nilai budayanya", sehingga kebudayaan Indonesia perlu dihayati oleh seluruh warga negara. Berdasarkan landasan konstitusi tersebut, kebudayaan Indonesia yang mencerminkan nilai-nilai luhur bangsa harus dilestarikan guna memperkukuh jati diri bangsa, mempertinggi harkat dan martabat bangsa, memperkuat ikatan rasa kesatuan dan persatuan, memperkuat pengamalan Pancasila, meningkatkan kualitas hidup, memperkuat dan memperkukuh persatuan bangsa, serta meningkatkan kesejahteraan masyarakat sebagai arah kehidupan bangsa demi terwujudnya cita-cita bangsa pada masa depan.

Berdasarkan amanat UndangUndang Dasar Negara Republik Indonesia Tahun 1945, Pemerintah mempunyai kewajiban memajukan kebudayaan secara utuh untuk sebesar-besarnya kemakmuran rakyat. Sehubungan dengan itu, seluruh hasil karya bangsa Indonesia, baik pada masa lalu, masa kini, maupun yang akan datang, perlu dimanfaatkan sebagai modal pembangunan. Sebagai karya warisan budaya masa lalu, cagar budaya dan bukan cagar budaya menjadi perlu untuk dipertahankan keberadaannya karena mengandung nilai-nilai penting bagi umat manusia, seperti sejarah, estetika, ilmu pengetahuan, etnologi, dan keunikan yang terwujud dalam bentuk Benda Cagar Budaya, Bangunan Cagar Budaya, dan/atau Struktur Cagar Budaya dan Bukan Cagar Budaya. Oleh karena itu, upaya pelestariannya mencakup tujuan untuk melindungi, 
mengembangkan, dan memanfaatkannya.

Membangun Indonesia harus berlandas dari nilai-nilai kebangsaan yang ada. Namun pada masa sekarang ini nilainilai tersebut mulai memudar. Generasi penerus bangsa lebih bangga dengan kebudayaan asing dengan tergerusnya mereka ke dalam arus globalisasi. Mereka kehilangan kepercayaan pada bangsa sendiri. Lebih bangga menggunakan produk-produk asing. Sehingga dperlukan suatu upaya agar nilai-nilai kebangsaan dapat berkembang dan dijiwai oleh seluruh rakyat untuk membangun karakter bangsa.

Salah satu upaya pemerintah dalam menumbuhkan karakter bangsa adalah dengan menjalankan Pendidikan Karakter. Dalam Undang-Undang Nomor 20 Tahun 2003 Pasal 1 ayat 1 disebutkan bahwa "Pendidikan adalah usaha sadar dan terencana untuk mewujudkan suasana belajar dan proses pembelajaran agar peserta didik secara aktif mengembangkan potensi dirinya untuk memiliki kekuatan spiritual keagamaan, pengendalian diri, kepribadian, kecerdasan, akhlak mulia, serta keterampilan yang diperlukan dirinya, masyarakat, bangsa dan Negara". Dalamayat 11 disebutkan bahwa "Satuan pendidikan adalah kelompok layanan pendidikan yang menyelenggarakan pendidikan pada jalur formal, nonformal, dan informal pada setiap jenjang dan jenis pendidikan. Yang dimaksud dengan pendidikan informal sesuai dengan ketentuan dari ayat 13 adalah keluarga dan lingkungan.

Berdasarkan hasil penelitian yang dilakukan oleh Sari (2015) yang berjudul "Revitalisasi Nilai-Nilai Kebangsaan Melalui Komunitas Omah Budaya Indonesia di Kota Surakarta". Dalam hasil penelitiannya disimpulkan bahwa: 1) Upaya revitalisasi nilai-nilai kebangsaan yang mulai pudar melalui Komunitas Omah Budaya Indonesia mampu memunculkan beberapa nilai kebangsaan diantaranya: (a) dalam kegiatan diskusi, nilai yang muncul adalah nilai keseimbangan dan nilai demokrasi, (b) dalam kegiatan latihan nilai yang muncul adalah nilai keseimbangan,nilai religius, dan nilai kemanusiaan, (c) dalam kegiatan pementasan nilai yang muncul adalah nilai religius; nilai-nilai yang muncul sesuai dengan contoh sikap positif yang berkaitan dengan nilai-nilai kebangsaan yang terkandung dalam Konstitusi UndangUndang Dasar Negara Republik Indonesia Tahun 1945. Penelitian tersebut membuktikan bahwa penanaman nilai-nilai kebangsaan tidak hanya di lakukan melalui pendidikan formal ataupun pendidikan non formal, tetapi bisa juga melalui pendidikan informal yaitu lingkungan.

\section{METODE}

Pendekatan yang digunakan dalam penelitian ini adalah pendekatan deskriptif. Alasan peneliti melakukan penelitian dengan metode deskriptif adalah karena sesuai dengan sifat dan tujuan penelitian yang ingin diperoleh bukan menguji hipotesis tetapi berusaha mendapat gambaran nyata tentang "Peran Museum Brawijaya Sebagai Wahana Internalisasi Nilai-nilai Kebangsaan".

Jenis penelitin yang digunakan adalah penelitian kualitatif karena akan menghasilkan data yang dikumpulkan berupa tulisan, kata-kata, gambar, dan bukan angka-angka. Jadi selama proses penelitian ini, peneliti akan lebih lebih banyak berhubungan atau mengadakan kontak dengan subyek penelitian di Museum Brawijaya.

Penelitian ini dilakukan di Museum Brawijaya, tepatnya terletak di Jalan Ijen Nomor 25A Kota Malang, Jawa Timur, Indonesia. Museum Brawijaya dipilih sebagai lokasi penelitian dikarenakan museum ini dapat menunjang hasil penelitian yaitu sebagai wahana internalisasi nilainilai kebangsaan dengan memperlihatkan pengunjungnya alat-alat perlengkapan perang, benda-benda peninggalan sejarah, 
perpustakaan museum yang merupakan tempat mengoleksi buku-buku dan dokumen-dokumen (audio visual) sejarah TNI, karya-karya umum dan referensi yang terkait dengan pengabdian terhadap Negara Kesatuan Republik Indonesia.

Sugiyono (2014) Teknik pengumpulan data merupakan langkah yang paling strategis dalam penelitian, karena tujuan utama dari penelitian adalah mendapat kandata. Tanpa mengetahui teknik pengumpulan data, maka peneliti tidak akan mendapatkan data yang memenuhi standar data yang ditetapkan.

Milles dan Hubarman (dalam Gunawan, 2013) mengemukakan bahwa terdapat tiga tahapan yang harus dikerjakan dalam menganalisis data penelitian kualitatif, yaitu (a) Reduksi data (data reduction); (b) Paparan data (data display); (c) dan penarikan kesimpulan dan verifikasi (conclution drawing/verifying).

Bermacam-macam cara pengujian keabsahan data atau kepercayaan terhadap data hasil penelitian kualitatif antara lain dilakukan dengan cara perpanjangan pengamatan peningkatan ketekunan, triangulasi, diskusi dengan teman sejawat, analisis kasus negatif, dan membercheck.

\section{HASIL DAN PEMBAHASAN Peran Museum Brawijaya Sebagai Wahana Internalisasi Nilai-Nilai Kebangsaan}

Peran Museum Brawijaya dalam menginternalisasi nilai-nilai kebangsaan terhadap masyarakat khususnya pemuda dilakukan dalam berbagai aksi, antara lain:

a. Pengkomunikasian Benda-benda Koleksi Museum Brawijaya Kepada Pengunjung

Peran Museum Brawijaya dalam menanamkan nilai-nilai kebangsaan terhadap pengunjung adalah dengan mengkomunikasikan benda-benda koleksi Museum Brawijaya kepada pengunjung, sehingga komunikasi ini memiliki peranan penting dalam keberhasilan penyampaian pesan. Dengan mengajak pengunjung berkeliling melihat museum, petugas museum memberikan informasi yang terkait dengan koleksi-koleksi Museum. Harapannya adalah agar nilainilai kebangsaan itu dapat diinternalisasi atau dihayati oleh para pengunjung.

Pengkomunikasian koleksi-koleksi museum juga dilakukan oleh pengelola secara tidak langsung atau tanpa tatap muka yaitu dengan mencantumkan penjelasan singkat pada setiap koleksi. Pengkomunikasian secara tidak langsung bertujuan agar pengunjung tetap mendapatkan informasi tentang koleksi meskipun tanpa didampingi oleh pemandu Museum. Pengkomunikasian koleksi juga memperhatikan pada jenjang pendidikan. Tujuannya adalah agar penyampaian informasi dapat terserap dengan baik. Untuk pengunjung dari kalangan Kelompok Bermain ataupun Taman Kanak-Kanak (TK) dan SD, diberikan informasi secara garis besar, sedangkan untuk siswa SMP, SMA, mahasiswa atau bahkan masyarakat umum diberikan informasi secara lebih terperinci atau mendalam.

\section{b. Pameran Keliling}

Peran Museum Brawijaya dalam menamkan nilai-nilai kebangsaan adalah dengan melakukan program-program seperti pameran kelilingyang dilakukan di berbagai daerah khususnya daerah Jawa Timur. Pameran keliling ini menampilkan koleksi-koleksimuseum baik berupa senjata perang maupun seragam-seragam yang dulu pernah dikenakan oleh para pejuang. Pameran keliling dilaksanakan atas kerja sama dengan dengan dinas ataupun instansi terkait. Biasanya pameran dilakukan untuk memperingati hari besar nasional. Hingga saat ini Museum Brawijaya selalu aktif dalam berbagai kegiatan pameran. Museum pernah mengikuti pameran di Kota Probolinggo, Surabaya, Kediri, Jember, Sampang, Madura, dan kota-kota lainnya. Tujuan dari pameran keliling ini adalah agar museum tidak hanya dikenal oleh masyarakat Jawa Timur tetapi juga di seluruh Nusantara. 
Sistem Pengelolaan Museum Brawijaya

Pengelolaan museum dilakukan untuk keberlangsungan aktivitas museum, mulai dari cara museum manarik perhatian pengunjung Sumber Daya Manusia (SDM) untuk menunjang pengelolaan museum, pengelolaan teknis koleksi, pengelolaan pendanaan museum, serta sistem pengelolaan perpustakaan museum.

a. Menarik Perhatian Pengunjung

Pengunjung merupakan salah satu bukti keberhasilan museum dalam menarik perhatian masyarakat terutama kaum muda. Semakin banyak pengunjung berarti semakin baik cara yang dilakukan oleh museum untuk menarik perhatian. Dan sebaliknya, apabila sedikit pengunjung yang berkunjung, berarti museum belum berhasil dalam menarik perhatian masyarakat. Pengunjung museum Brawijaya tidak selalu sepi dan tidak selalu ramai. Pada hari-hari biasa, pengunjung Museum Brawijaya terbilang sepi yaitu antara 7-15 orang per hari, sementara pada akhir pekan, menjelang dan saat liburan semester pengunjung museum terbilang ramai yaitu antara 50-100 orang terutama dari kalangan pelajar karena biasanya merupakan bagian dari program dan bentuk kerja sama antara museum dengan sekolah.

Untuk dapat menarik perhatian masyarakat agar berkunjung ke museum, terdapat beberapa upaya yang dilakukan oleh museum, yaitu dengan kerapian penataan benda-benda koleksi, menjaga kebersihan museum untuk kenyamanan pengunjung, mengecat bangunan gedung, pameran keliling, dan pameran busana.

b. Sumber Daya Manusia

Sumber Daya Manusia adalah salah faktor keberhasilan museum dalam pengelolaan museum. Karena pemeran utama dalam proses pengelolaan museum adalah sumber daya manusia. Museum Brawijaya dikepalai oleh Kapten CAJ (K) Luluk Lutminarti dan dikelola oleh jajaran Anggota TNI Angkatan Darat dan Pegawai Negeri Sipil (PNS) yaitu anggota-anggota yang berada di bawah satuan Pembinaal Mental Daerah Militer V/Brawijaya (Bintaldam V/Brawijaya). Total seluruh pengelola museum ada 8 orang dengan pembidangan yaitu bidang pengamanan, informasi, pemandu, dan perpustakaan. Pembidangan dilakukan secara berkala yaitu setiap satu minggu, sehingga seluruh pengelola diwajibkan untuk bisa melaksanakan seluruh pembidangan tersebut. Sebelum menjadi pengelola museum, para anggota TNI dan PNS tersebut diberikan pelatihan atau kursus tentang permuseuman berdasarkan golongan. Golongan I atau Tamtama diberikan Kursus Tamtama Pengamanan Museum. Yang ke dua Bintara atau Golongan II diberikan kursus Bintara Sejarah dan Permuseuman. Kemudian untuk golongan III dan Perwira, diberikan kursusnya Kursus Perwira Sejarah, maupun Kursus Perwira Dokumen dan Perpustakaan. Kursus yang diadakan oleh TNI dan wajib diikuti selama tiga bulan setengah.

c. Pengelolaan Pendanaan Museum

Sumber pendanaan tetap museum adalah dari Bintaldam V/Brawijaya (Pembinaan Mental Daerah Militer V/ Brawijaya) karena museum ini adalah berada di bawah naungan Bintaldam Brawijaya. Segala sesuatu yang dibutuhkan untuk keberlangsunan aktivitas di museum menjadi tanggung jawab Bintaldan V/ Brawijaya. Sementara untuk gaji pengelola menjadi tanggung jawab negara karena semua pengelola museum merupakan anggota TNI-AD dan PNS. Pendanaan lain juga didapat dari dinas Provinsi tingkat I tetapi dalam bentuk barang.

Berdasarkan hasil dokumentasi, pendanaan juga diperoleh dari hasil penjualan tiket, pakan ikan, kantin, layanan kamarkecil(toilet). Biaya tiket masuk untuk pengunjung adalah sebesar Rp. 3.000 baik untuk anak-anak maupun dewasa. Karena 
di depan halaman depan terdapat kolam ikan, museum juga menyediakan pakan ikan yang bisa dibeli oleh pengunjung yang ingin memberi makan ikan-ikan di kolam. Harga pakan tersebut adalah Rp. $2.000 /$ bungkus $(1 / 4 \mathrm{~kg})$. Selain itu museum juga membuka kantin yang berisi makanan ringan dan minuman cepat saji yang bisa dibeli pengunjung dengan harga terjangkau yaitu mulai dari Rp. 5.000 sampai dengan Rp. 20.000. Selain itu museum juga menyediakan layanan toilet umum bagi para pengunjung. Pengguna layanan ini dikenakan tarif berdasarkan ketentuan yaitu Rp. 1.000 apabila buang air kecil dan Rp. 2.000 apabila buang air besar maupun mandi.Hasil dari layanan-layanan tersebut digunakan untuk bantuan pendanaan museum seperti untuk perawatan gedung, halaman, maupun koleksi.

\section{d. Pengelolaan Teknis Koleksi}

Koleksi MuseumBrawijaya diperoleh melalui tiga cara, yaitu hasil perampasan dari penjajah pada zaman peperangan merebut kemerdekaan, tugas operasi, dan hibah atau pemberian. Pemberian biasanya dilakukan oleh masyarakat umum atapun instansi-instansi.Penataan benda-benda koleksi juga memperhatikan sejarah dari masing-masing koleksi dengan tujuan agar pengunjung bisa memahami proses awal hingga akhir dari perjuangan Indonesia melawan penjajah. Pengeolaan teknis koleksi dilakukan dengan penyimpanan dan pemeliharaan. Penyimpanan koleksi dilakukan pada ruangan terbuka dan rungan tertutup.Koleksi disimpan dalam ruang penyimpanan terbuka apabila bentuk dan ukurannya tidak memungkinkan untuk disimpan di ruang penyimpanan tertutup. Untuk menjaga benda-benda koleksi agar tetap awet dan tidak mudah rusak, koleksi di simpan di dalam tempat yang aman. Misalnya seragam tentara yang disimpan di lemari kaca, senjata-senjata berukuran kecil dan mengelilingi benda-benda koleksi menggunakan rantai, museum melarang pengunjung untuk memegang secara keras, dan pengunjung juga dilarang untuk mengoperasikan koleksi.

e. Pengelolaan Perpustakaan Museum

Perpustakaan Museum Brawijaya juga seperti perpustakaan lain pada umumnya. Pengunjung perpustakaan tidak hanya berasal dari dalam negeri tetapi juga dari luar negeri seperti Amerika Serikat, Korea Utara, Korea Selatan, India, dan Thailand baik dari golongan pelajar, mahasiswa, masyarakat umum, dan anggota TNI-AD. Pengunjung perpustakaan terkadang ramai ketika pengunjung museum juga ramai, biasanya saat menjelang kenaikan kelas dan musim liburan.

Untukmengetahui indeks pengunjung perpustakaan, pengelola melakukan pengkajian dengan membuat grafik yang bersumber dari buku pengunjung perpustakaan. Pengkajian dilakukan setiap bulan. Koleksi perpustakaan Museum Brawijaya diperoleh dari Angkatan Darat itu sendiri yaitu dari DISJARAHAD atau Dinas Sejarah Angkatan Darat.Selain itu juga diperoleh dari pegadaan lain, yang dianggarkan oleh Bintaldam, maupun para sukarelawan baik dari masyarakat umum. Koleksi yang ada di Perpustakaan sebagai mana dengan koleksi perpustakaan -perpustakaan yang lain yaitu dari karya umum, karya-karya bahasa, biografi, serta sosial. Koleksi buku perpustakaan yang paling banyak adalah karya sosial yang memiliki kaitannya dengan perjuangan bangsa Indonesia terutama perjuangan masyarakat Jawa Timur.

\section{Respon Pengunjung Terhadap Nilai- Nilai Kebangsaan Yang Terdapat Di Dalam Museum Brawijaya}

Museum Brawijaya adalah salah satu museum di Kota Malang yang berfungsi sebagai tempat rekreasi sekaligus edukasi tentang sejarah perjuangan kemerdekaan Indonesia. Dengan mengunjungi Museum Brawijaya, pengunjung dapat melihat 
langsung benda-benda yang digunakan oleh para pahlawan untuk mengusir penjajah. Selain itu terdapat pula bendabenda yang berhasil dirampas dari tangan penjajah. Kisah-kisah perjuangan tersebut membuat kalangan pelajar, mahasiswa, maupun dari masyarakat umum tertarik untuk berkunjung ke Museum Brawijaya ini.

Setelah mengunjungi Museum Brawijaya, muncul respon yang berbedabeda dari para pengunjung tentang kepuasan mereka. Nilai-nilai kebangsaan yang dapat tumbuh dan dan berkembang setelah mengunjungi Museum Brawijaya di kalangan pemuda pada khususnya dan masyarakat pada umumnya, antara lain sebagai berikut:

a. Rela Berkorban

Rela artinya bersedia dengan senang hati dan tidak mengharapkan imbalan atas dasar kemauan sendiri. Berkorban artinya memberikan segala sesuatu yang dimiliki sekaligus menimbulkan penderitaan bagi dirinya sendiri. Sikap rela berkorban adalah sikap yang mencerminkan adanya kesediaan dan keikhlasan dalam memberikaan sesuatu yang dimilikiuntuk orang lain, walaupun akan menimbulkan penderitaan bagi diri sendiri. Dalam pengertian yang lebih sederhana, rela berkorban adalah sikap dan perilaku yang tindakannya dilakukan dengan ikhlas serta mendahulukan kepentingan orang lain daripada keuntungan diri sendiri. Atau dapat diartikan orang rela berkorban orang yang mau mengorbankan dirinya sendiri demi membahagiakan atau memenuhi kebutuhan orang lain.

b. Patriotisme

Patriotisme adalah sikap yang berani, pantang menyerah, dan rela berkorban demi bangsa dan negara. Patriotisme berasal dari kata "patriot" dan "isme" yang berarti sifat kepahlawanan atau jiwa pahlawan atau "heroisme"dan "patriotism" dalam bahasa Inggris. Pengorbanan ini dapat berupa prngorbanan harta benda maupun jiwa raga.

c. Integritas Bangsa

Integritas merupakan rasa suasana kebatinan dan keutuhan yang berasal dari kualitas seperti kejujuran atau konsistensi karakter. Integritas nasional sebagai upaya atau proses pembaruan berbagai aspek menjadi ciri dan atribut bangsa yang harus dapat menjamin terwujudnya keselarasan, keserasian, dan keseimbangan dalam mencapai tujuan bersama sebagai suatu bangsa.

d. Cinta Tanah Air

Cinta tanah air adalah perasaan yang timbul dari dalam hati sanubari seorang warga negara untuk mengabdi, memelihara, membela, melindungi, tanah airnya dari segala ancaman dan gangguan. Pengertian lain mengenai cinta tanah air adalah rasa kebanggaan, rasa memiliki, rasa menghargai, rasa menghormati, dan loyalitas yang dimiliki oleh setiap individu pada negara tempat ia tinggal yang tercermin dari perilaku membela tanah airnya, menjaga dan melindungi tanah airnya, rela berkorban demi kepentingan bangsa dan negaranya, mencintai adat atau budaya yang ada di negaranya dengan melestarikannya.

e. Bela Negara

Bela negara adalah sebuah konsep yang disusun oleh perangkat perundangan dan petinggi suatu negara tentang patriotisme seseorang, suatu kelompok atau seluruh komponen dari suatu negara dalam kepentingan mempertahankan eksistensi negara tersebut. Pembelaan negara bukan semata-mata tugas TNI, tetapi tugas segenap warga negara sesuai dengan kemampuan dan profesinya dalam kehidupan bermasyarakat, berbangsa, dan bernegara.

f. Cinta Produk Indonesia

Mencintai produk Indonesia atau produk dalam negeri merupakan bagian dari rasa nasionalisme kita sebagai bangsa Indonesia. Memiliki banyak alasan untuk mencintai produk dalam negeri, dan sudah 
merupakan keharusan bagi warga negara agar mencintai produk-produk dalam negeri agar produk dalam negeri itu sendiri bisa bersaing di kancah internasional. Namun dalam kenyataannya banyak produk dalam negeri yang jadi pemasok dengan merkmerk mahal dan terkenal dari luar negeri.

\section{SIMPULAN}

Museum Brawijaya telah melaksanakan perannya sebagai wahana internalisasi nilai-nilai kebangsaan bagi para pengunjung terutama generasi muda. Cara yang dilakukan oleh Museum Brawijaya sebagai bentuk perannya dalam menginternalisasi nilai-nilai kebangsaan adalah dengan mengkominikasikan koleksikoleksi museum kepada pengunjung dan ikut serta atau aktif dalam pameran-pameran yang diselenggarakan oleh instansi-instansi terkait. Terdapat beberapa sistem pengelolaan di Museum Brawijaya yaitu cara menarik perhatian pengunjung, pengelolaan sumber daya manusia, pendanaan, pengelolaan teknis koleksi, dan pengelolaan pada perpustakaan museum.

Terdapat berbagai alasan pengunjung mengunjungi Museum Brawijaya. Diantara adalah karena rasa ingin tahu, penasaran, atau bahkan hanya karena ajakan teman semata. Sehingga atas alasan tersebut menentukan tingkat kepuasan pengunjung masing-masing. Pengunjung yang datang karena rasa penasaran dn ingin tahu cenderung lebih puas karena mereka telah bisa melihat langsung benda-benda koleksi sejarah. Sementara pengunjung yang datang hanya karena ajakan teman, cenderung tidak puas karena tidak ada rasa antusias untuk mengunjungi tempattempat bersejarah. Nilai-nilai kebangsaan yang bisa pengunjung dapatkan, antara lain: 1) Menempatkan kepentingan bangsa dan negara di atas kepentingan pribadi, 2) Sanggup dan rela berkorban untuk bangsa dan negara, 3) Mencintai tanah air dan bangsa, 4) Bangga berbangsa dan bernegara
Indonesia, 5) Menjunjung tinggi persatuan dan kesatuan berdasarkan prinsip Bhineka Tungga Ika, 6) Memajukan pergaulan untuk meningkatkan persatuan dan kesatuan bangsa dan negara.

\section{DAFTAR PUSTAKA}

Gunawan, I. 2014. Metode Penelitian Kualitatif: Teori dan Praktik. Jakarta: Bumi Aksara.

Musa, A. M. 2011. Nasionalisme Di Persimpangan. Jakarta: Penerbit Erlangga.

Riva'i. A. 2000. Student Indonesia Di Eropa. Jakarta: Kepustakaan Populer Gramedia.

Sari, P. E. 2015. Revitalisasi Nilai-Nilai Kebangsaan Melalui Komunitas Omah Budaya Indonesia Di Kota Surakarta. Other Thesis Universitas Sebelas Maret (Online) http://eprints. uns.ac.id diakses 1 Desember 2015.

Sugiyono. 2014. Metode Penelitian Kualitatif Kuantitatif dan $R \& d$. Bandung: Alfabeta.

Sutrisno, Slamet. 1988. Pancasila: Kebudayaan dan Kebangsaan. Yogyakarta, Liberty.

BPKP. Peraturan Pemerintah Republik Indonesia Nomor 19 Tahun 1995 Tentang Pemeliharaan dan Pemanfaatan Benda Cagar Budaya Di Museum. (Online) http://www.bpkp.go.id diakses 1 Desember 2015.

Kemdikbud. Undang-Undang Nomor 11 Tahun 2010 Tentang Cagar budaya. (Online) http://cagarbudaya. kemdikbud.go.id diakses 1 Desember 2015.

Mahkamah Konstitusi RI. Undang-Undang Dasar Negara Republik Indonesia Tahun 1945 (Online) http://www. mahkamahkonstitusi.go.id diakses 18 Desember 2015. 